\title{
Summer Movements and Impact of Individual Striped Skunks, Mephitis mephitis, on Duck Nests in Saskatchewan
}

\author{
Serge Larivière ${ }^{1,3}$, Lyle R. WALton $^{2}$, and FrançOIS MESSIER ${ }^{3}$ \\ ${ }^{1}$ Delta Waterfowl Foundation, R.R. 1, Box 1, Site 1, Portage La Prairie, Manitoba R1N 3A1 Canada. Present address: Cree \\ Hunters and Trappers Income Security Board, 2700 boulevard Laurier, Champlain \# 1110, Québec (Québec) G1V 4K5 \\ Canada \\ ${ }^{2}$ Wildlife Research and Development Section, Ontario Ministry of Natural Resources, Ontario Government Complex, Hwy \\ 101 E., P.O. Bag 3020, South Porcupine, Ontario P0N 1H0 Canada \\ ${ }^{3}$ Department of Biology, University of Saskatchewan, 112 Science Place, Saskatoon, Saskatchewan S7N 5E2 Canada
}

Larivière, Serge, Lyle R. Walton, and François Messier. 2006. Summer movements and impact of individual Striped Skunks, Mephitis mephitis on duck nests in Saskatchewan. Canadian Field-Naturalist 120(3): 342-346.

Striped Skunks (Mephitis mephitis) are important predators of duck eggs in the Canadian prairies. We estimated the impact of individual Striped Skunks on duck nests by intensive observations of foraging movements and depredation of duck nests in southern Saskatchewan, 1993-1994. Nightly, skunk movements were variable (range 0-20 km per night), and did not differ among seasons for females, or between males and females during the parturition/rearing season. Overall, nightly movement of Striped Skunks averaged $7.4 \mathrm{~km}$ for females $(\mathrm{SD}=5.9 \mathrm{~km}, n=20$ females) and $6.7 \mathrm{~km}$ for males $(\mathrm{SD}=3.2 \mathrm{~km}, n=5$ males). During $1873 \mathrm{~h}$ of radio-tracking, we observed depredation of 10 duck nests by 8 skunks (7 F, $1 \mathrm{M})$. Using our observed estimate of one depredation for every $187 \mathrm{~h}$, and averaged nightly activity of 8-10 h per night, we estimated that individual skunks find one duck nest every 19-23 nights. Thus, during the 60-day nesting season for ducks (mid-May to mid-July), individual skunks probably find 2-3 duck nests. These observations reinforce the growing evidence that, at normal duck nest densities (<2.5 nests/ha), depredation of eggs by Striped Skunks is opportunistic, and the impact of Striped Skunks on duck nests is a direct function of Striped Skunk abundance.

Key Words: Striped Skunk, Mephitis mephitis, duck, movement, nest predation, prairie, predator ecology, Thickwood Hills, Saskatchewan.

Predation on eggs is an important limiting factor for many bird populations (Ricklefs 1969; Martin 1995). In the grasslands of North America, population decline of many species of ground nesting birds is attributed to increased predation on eggs during the breeding season (Böhning-Gaese et al. 1993). Of these birds, ducks (Anatidae) nesting in the prairies of Canada and the United States experience high predation rates on their nests. The primary mammalian predators are Striped Skunks (Mephitis mephitis), Red Foxes (Vulpes vulpes), Raccoons (Procyon lotor), American Badgers (Taxidea taxus) and Coyotes (Canis latrans). The impact of these predators on duck nest success is well recognized (Klett et al. 1988; Johnson et al. 1989; Pasitschniak-Arts and Messier 1995). However, the contribution of individual animals is poorly understood, yet is critical for management and mitigation of nest predation.

In the parklands of Saskatchewan, the Striped Skunk is an important predator of duck eggs (PasitschniakArts and Messier 1995), yet it depredates duck nests opportunistically (Larivière and Messier 1997a, 1998a). This suggests that the impact of skunks on duck nest success is the result of "chance" encounters with duck nests as skunks forage for other foods such as small mammals and insects (Greenwood et al. 1999). Therefore, the impact of Striped Skunks on duck nests should be a function of (a) habitat selection patterns (do skunks use habitats where ducks nest?), (b) movement rates (the longer the movements by skunks, the greater the chances of discovering a duck nest), and (c) density of skunks (the more skunks, the greater the impact on duck nests). A recent experiment suggested that individual predators were unlikely to key on duck nests at densities <2.5 nests/ha (Larivière and Messier 1998a). Furthermore, partial depredation of duck nests by Striped Skunks commonly occurs (Larivière and Messier 1997a; Ackerman 2002), suggesting that duck eggs may not be a preferred food of skunks or that their importance may be marginal to the overall nutrition of Striped Skunks. An estimate of the impact of individual Striped Skunks on duck nests would help further our understanding of the role that duck eggs play in the foraging ecology of this carnivore. Herein, we estimate the impact of individual Striped Skunks on duck nests by combining intensive radio-tracking and observations of free-ranging Striped Skunks in the Prairie Pothole Region of Saskatchewan, Canada.

\section{Methods}

We conducted this study ca. $80 \mathrm{~km}$ northwest of Saskatoon in the Thickwood Hills of southcentral Saskatchewan, Canada $\left(52^{\circ} 45^{\prime} \mathrm{N}, 107^{\circ} 08^{\prime} \mathrm{W}\right)$. In 1993 , the area (ca. $220 \mathrm{~km}^{2}$ ) was dominated by farmland and interspersed with many wetlands and stands of trem- 
bling aspen (Populus tremuloides). Cropland represented $66 \%$ of the area, and was primarily used for the production of grain (e.g., wheat, barley, rye, and oats), and oil crops (e.g., canola and flax). Other less common crops included peas, lentils, buckwheat, and canary seed. Woodland and areas managed for nesting waterfowl (mostly dense nesting cover) occupied 11\% and 9\% of the landscape, respectively. Managed nesting areas consisted mostly of dense nesting cover, hay land, and idle pastures. Fields of dense nesting cover were sown with various tame and wild grasses to create prime habitat for nesting waterfowl. Small or linear cover types such as wetlands, rights-of-way, farmsteads, and miscellaneous habitats represented $8 \%, 4 \%, 1 \%$, and $1 \%$ of the land available, respectively. Topography was gently rolling, and an extensive network of roads divided the land.

In 1993, Striped Skunks were live-trapped using opaque-sided livetraps (Dura-Poly livetraps, Ram Supplies, Birtle, Manitoba). Captured skunks were anesthetized with halothane and Telazolß) (Larivière and Messier 1996a, 1996b), and equipped with motionsensitive radio-collars (Telonics Inc., Mesa, Arizona, USA). Skunks were handled and released at site of capture.

Radio-collared animals were located and tracked by a single observer on foot from 18:00 to 06:00 h, during the period of greatest activity (Larivière and Messier 1997b). During tracking, a single observer followed the foraging skunk while remaining downwind, and usually within $15-50 \mathrm{~m}$ of the animal (Larivière and Messier 1998b). This distance allowed precise location of focal animals every $15 \mathrm{~min}$, and allowed observation of foraging behavior. For short movements $(<100 \mathrm{~m})$, distance from previous location was estimated by observer. Locations immediately following an observer-induced defensive posture ( $n=198$ : Larivière and Messier 1996c) were discarded from analyses because of observer disturbance (Larivière and Messier 1998b). At dark, we used night-vision equipment (AN-PVS 5C, Bill's Electronics, Mildmay, Ontario) to continue observations (Larivière and Messier 1998b). Encounters with duck nests typically were easy to detect because of the flushing hen (Larivière and Messier 1997a) or repeated visits to the nest (Larivière and Walton 1998). Depredated nests were investigated immediately following departure of the skunk, and usually reexamined the following day.

For each location, we recorded position of the focal skunk using a Global Positioning System (GPS) unit. We estimated accuracy of our GPS as $\pm 250 \mathrm{~m}$. To overcome biases associated with the inaccuracy of our GPS on short movements, we only considered the total distance traveled by each skunk during the 12-h tracking period (sum of all 15-min movements). We also only considered complete 12-h blocks for which onset and cessation of activity were known. Missing values (typically caused by delays of the GPS unit to obtain fixes in forested habitats) for $\leq 2$ intervals per night were approximated by the nightly mean of 15 -min travel distances. Sessions with > 2 missing values were discarded from analyses. Biological seasons for Striped Skunks were identified as pre-parturition (1 April-14 May), parturition/rearing (15 May- 30 June), pre-dispersal (1-31 July), and dispersal (1-31 August).

Each summer (May-August), $>50 \%$ of radio-collared animals died or dispersed outside the study area (Larivière and Messier 1998c). Thus, the resulting data set was not balanced, and precluded use of repeatedmeasures analyses, and comparison among seasons. Therefore, we used a one-way analysis of variance to test for effects of season on movements. To avoid biases caused by animals tracked $>1$ night in a given season, we used the mean distance traveled for each skunk in each season (weighted mean, only one value per animal per season). Because some skunks were tracked during more than one season and they may not have been independent, we used an alpha value of 0.01 to remain conservative and reduce the chance of a Type 1 error.

\section{Results}

During 1993 and 1994, we obtained complete movement information for 63 12-h tracking sessions (11 in 1993, and 52 in 1994) on 25 Striped Skunks (5 M, 20 F). Because no skunks were radio-tracked during both years, we pooled data from 1993 and 1994 for analyses.

Nightly movements of female Striped Skunks during pre-parturition (mean $=4.2 \mathrm{~km}, \mathrm{SD}=4.9 \mathrm{~km}, n=4)$, parturition $/$ rearing $($ mean $=7.2 \mathrm{~km}, \mathrm{SD}=6.1 \mathrm{~km}$, $n=19$ ), pre-dispersal (mean $=5.6 \mathrm{~km}, \mathrm{SD}=3.0 \mathrm{~km}$, $n=8)$, and dispersal $($ mean $=3.0 \mathrm{~km}, \mathrm{SD}=3.1, n=2)$ were not statistically different $\left(\mathrm{F}_{3,29}=0.70, P=0.56\right)$. Distance traveled during 12-h tracking sessions were variable and ranged from 0.0 to $20.3 \mathrm{~km}$ per night (mean $=6.2 \mathrm{~km}, \mathrm{SD}=5.2 \mathrm{~km}, n=33$ female-season). When we considered only one value for each female (weighted mean; average of all seasons), nightly movements averaged $7.4 \mathrm{~km}$ (SD $=5.9 \mathrm{~km}, n=20$ females $)$.

During the parturition/rearing season, movements of males $($ mean $=6.7 \mathrm{~km}, \mathrm{SD}=3.2 \mathrm{~km}, n=5)$ did not differ ( $t$-test, df $=22, P=0.84$ ) from movement of females $($ mean $=7.2, \mathrm{SD}=6.1 \mathrm{~km}, n=19)$. Movements of all skunks during the parturition/rearing period averaged $7.1 \mathrm{~km}(\mathrm{SD}=5.6 \mathrm{~km}, n=24$ skunks $)$.

During spring and summer 1993 and 1994, we radiotracked Striped Skunks for 1873 h (858 h in 1993, and $1015 \mathrm{~h}$ in 1994). During radio-tracking, we observed depredation of 10 duck nests (4 in 1993, 6 in 1994), thus averaging one depredation event for every $187 \mathrm{~h}$ of radio-tracking ( 1 for $215 \mathrm{~h}$ of radio-tracking in 1993 , and 1 for $169 \mathrm{~h}$ in 1994). Observed depredation events were caused by 8 Striped Skunks ( 7 females, 1 male). Observed depredation events occurred between 9 June and 9 July in 1993, and between 15 May and 20 July in 1994. 
From our observations, we extrapolated the number of nests depredated by a skunk during the duck nesting season. First, using our rate of discovery of 1 nest every $187 \mathrm{~h}$ of tracking, and allowing an average 8$10 \mathrm{~h}$ of foraging movements per night (Larivière and Messier 1997b), we estimated that individual skunks found 1 duck nest for every 19-23 nights of foraging. Considering the duck nesting season lasts approximately $60 \mathrm{~d}$ (mid-May until mid-July), then individual skunks may find 2-3 duck nests per season. However, because skunks foraging in dense vegetation may have depredated duck nests without us noticing, this estimate represents a minimum number, but our closerange observations (typically $<50 \mathrm{~m}$ ) and use of nightvision equipment suggests that we did not miss many depredation events.

\section{Discussion}

Our results clearly show that the foraging behavior of Striped Skunks consists of highly variable foraging movements and opportunistic, but infrequent, depredation of duck nests. The variable movements we observed within and among seasons, or between sexes, precluded detection of statistical differences. However, the trend suggested that movements were shorter during the pre-parturition season, higher during parturition season, and declined temporally thereafter. Interestingly, the decline in skunk movements over time coincides with the steady increase in availability of both small mammals and insects over time (Larivière and Messier 2000). Although we could not statistically link movements of skunks and food abundance because of only four sampling periods, we nonetheless observed apparently reduced skunk movements over time as prey abundance increased. An experiment done with simulated nests in our study area in 1995 indicated that increases in availability of food (chicken eggs) caused a reduction of activity and home ranges in female Striped Skunks (Larivière and Messier 2001a).

Movement rates observed in our study are the largest reported for this species. However, most previous studies of skunk movements relied on distance between consecutive den sites (Shirer and Fitch 1970), maximum distance from the den during any given night (Verts 1967), or distance between recapture sites (Bjorge et al. 1981). Our study is one of three that reported actual distance moved from telemetry locations. In Illinois, daily movements of Striped Skunks averaged $1.7 \mathrm{~km}$ for males $(n=4)$ and $1.4 \mathrm{~km}$ for females $(n=9)$ (Storm 1972). In North Dakota, nightly movements ranged from 0.0 to $9.3 \mathrm{~km}$ for 26 females $($ mean $=2.7 \mathrm{~km})$, and from 0.4 to $10.5 \mathrm{~km}$ for males $($ mean $=3.3 \mathrm{~km})($ Greenwood et al. 1985). We believe our values are higher because we collected a more accurate description of movement paths by collecting locations at closer intervals (i.e., every $15 \mathrm{~min}$ ) whereas animals were located every $2 \mathrm{~h}$ in North Dakota (Greenwood et al. 1985), and at intervals varying between 10 and 120 minutes in Illinois (Storm 1972).

Two additional explanations may explain the long movements of Striped Skunks in our study area. The first may be the composition of the landscape. Our study area was primarily cropland (66\% of study area), a habitat that provides low abundance and diversity of foods for skunks (Larivière and Messier 2000). Not surprisingly, Striped Skunks in our study area avoided cropland when foraging (Larivière and Messier 2000). Thus, large amounts of cropland may contribute to increased movements as skunks were forced to travel across large fields to access prime habitats embedded therein. Nightly movements of Striped Skunks may be lower in large patches of continuous foraging habitats, a phenomenon that would help explain the typically higher nest success of ground-nesting birds in large patches of non-fragmented habitat (Pasitschniak-Arts and Messier 1996; Ball et al. 1995).

Another explanation may be related to the amount of food in the landscape. Possibly, food abundance may have been lower in our study area compared to previous studies, thus contributing to longer movements. Food supplementation experiments on Striped Skunks and other species typically yield lower activity, smaller ranges, and shorter foraging bouts (Boutin 1990; Larivière and Messier 1998a). However, because we have no way of comparing food abundance among studies, we can only speculate on whether differences existed between our study area and those used in previous studies.

Managers attempting to mitigate predation on duck nests need to know whether high predation rates occur because of specialized foraging by a few individuals depredating numerous nests, or simply by a high abundance of individuals each depredating only a few nests. Previous observations of skunk foraging behavior suggested that predation is incidental to foraging for other foods (Vickery et al. 1992; Larivière and Messier 1997a), and that greater predation rates are explained by a greater abundance of nest predators (Larivière and Messier 1998a).

Our study suggests that individual Striped Skunks in the Canadian prairies find between 0 and 3 duck nests per year. In fact, we observed only two skunks depredate more than one duck nest in any given year (both cases of females depredating two nests). Because our study area was located where nesting cover was common (managed nesting areas represented $9 \%$ of the study area), we believe our estimates probably are high because most areas of the Canadian prairies do not have $10 \%$ of the land as cover available for ducks, and hence probably hold fewer duck nests. Nonetheless, this suggests that availability of duck nests in the landscape is not high enough to warrant special foraging efforts; this reinforces the notion that nest depredation by Striped Skunks is strictly incidental (Larivière and Messier 1997a, 1998a, 2001b; Vickery et al. 1992). Finally, the rate of encounter suggests that the 
impact of skunks on duck nests is directly related to skunk abundance, as was previously suggested (Larivière and Messier 1998a).

The impact of individual Striped Skunks on duck nests provides insight into the low success of management techniques that aim at educating individual predators. For example, conditioned-taste aversion had been unsuccessful under field conditions when mammals such as skunks and Raccoons were the main predators (Clark et al. 1996). We believe our data suggest that encounter rates with duck nests by individual predators are too low for such techniques to be effective, notwithstanding problems in causing aversion (Clark et al. 1996). At normal nest densities (<1 nest/ha), predators cannot subsist on eating duck eggs alone, and duck eggs only represent a marginal food item (Greenwood et al. 1999). Not surprisingly, foraging activity of Striped Skunks is directed at habitats where base prey such as insects and small mammals are most abundant, and not in areas managed for nesting ducks (Larivière and Messier 2000). Thus, management techniques that aim to increase nest success should be directed at reducing predator abundance locally (Garretson and Rohwer 2001), or reducing overall habitat suitability for predators with implementation of largescale habitat programs through agricultural policies (e.g., Conservation Reserve Program in the United States, Reynolds et al. 2001).

\section{Acknowledgments}

This study was supported by the Prairie Habitat Joint Venture through a research grant from Ducks Unlimited (Institute for Wetland and Waterfowl Research), the Canadian Wildlife Service, as well as support from the Delta Waterfowl Foundation, the National Science and Engineering Research Council through and operating grant to SL, as well as postgraduate and postdoctoral fellowships from the Fonds pour la Formation de Chercheurs et l'Aide à la Recherche (FCAR), Québec. Field and laboratory assistance was provided by B. Dinter, E. Howard, G. Poon, B. Fry, K. Eade, H. Royer, P. Toner, S. Daviduik, and D. Anderson. J. Pitt, Y. T. Hwang, H. Nelson, and D. Murray reviewed earlier drafts of this manuscript. We followed a university-approved animal welfare protocol (\#920091) while conducting this research.

\section{Literature Cited}

Ackerman, J. T. 2002. Of mice and mallards: positive indirect effects of coexisting prey on waterfowl nest success. Oikos 99: 469-480.

Ball, I. J., R. L. Eng, and S. K. Ball. 1995. Population density and productivity of ducks on large grassland tracts in northcentral Montana. Wildlife Society Bulletin 23: 767773.

Bjorge, R. R., J. R. Gunson, and W. M. Samuel. 1981. Population characteristics and movements of striped skunks (Mephitis mephitis) in central Alberta. Canadian FieldNaturalist 95: 149-155.
Böhning-Gaese, K., L. M. Taper, and J. H. Brown. 1993. Are declines in North American insectivorous songbirds due to causes on the breeding range? Conservation Biology 7: 76-86.

Boutin, S. 1990. Food supplementation experiments with terrestrial vertebrates: patterns, problems, and the future. Canadian Journal of Zoology 68: 203-220.

Clark, R. G., K. L. Guyn, C. N. Penner, and B. V. Semel. 1996. Altering predator foraging behavior to reduce predation of ground-nesting birds. Transactions of the North American Wildlife and Natural Resources Conference 61: 1168-1226.

Garrettson, P. R., and F. C. Rohwer. 2001. Effects of mammalian predator removal on production of upland-nesting ducks in North Dakota. Journal of Wildlife Management 65: 398-405.

Greenwood, R. J., A. B. Sargeant, and D. H. Johnson. 1985. Evaluation of mark-recapture for estimating striped skunk abundance. Journal of Wildlife Management 49: 332-340.

Greenwood, R. J., A. B. Sargeant, J. L. Piehl, D. A. Buhl, and B. A. Hanson. 1999. Foods and foraging of prairie striped skunks during the avian nesting season. Wildlife Society Bulletin 27: 823-832.

Johnson, D. H., A. B. Sargeant, and R. J. Greenwood. 1989. Importance of individual species of predators on nesting success of ducks in the Canadian Prairie Pothole Region. Canadian Journal of Zoology 67: 291-297.

Klett, A. T., T. L. Shaffer, and D. H. Johnson. 1988. Duck nest success in the Prairie Pothole region. Journal of Wildlife Management 52: 431-440.

Larivière, S., and F. Messier. 1996a. Field anesthesia of striped skunks, Mephitis mephitis, using halothane. Canadian Field-Naturalist 110: 703-705.

Larivière, S., and F. Messier. 1996b. Immobilization of striped skunks using Telazol®. Wildlife Society Bulletin 24: 713-716.

Larivière, S., and F. Messier. 1996c. Aposematic behavior in the striped skunk (Mephitis mephitis). Ethology 102: 986-992.

Larivière, S., and F. Messier. 1997a. Characteristics of waterfowl nest depredation by the striped skunk, Mephitis mephitis: can predators be identified from nest remains? American Midland Naturalist 137: 393-396.

Larivière, S., and F. Messier. 1997b. Seasonal and daily activity patterns of striped skunks (Mephitis mephitis) in the Canadian prairies. Journal of Zoology London 243: 255-262.

Larivière, S., and F. Messier. 1998a. Effect of density and nearest neighbours on simulated waterfowl nests: can predators recognize high-density nesting patches? Oikos 83 : 13-20.

Larivière, S., and F. Messier. 1998b. The influence of closerange radio-tracking on the behavior of free-ranging striped skunks, Mephitis mephitis. Canadian Field-Naturalist 112: 657-660.

Larivière, S., and F. Messier. 1998c. Spatial organization of a prairie striped skunk population during the waterfowl nesting season. Journal of Wildlife Management 62: 199-204.

Larivière, S., and F. Messier. 2000. Habitat selection and use of edge by striped skunks in the Canadian prairies. Canadian Journal of Zoology 78: 366-372.

Larivière, S., and F. Messier. 2001a. Space-use patterns of female striped skunks exposed to aggregations of simu- 
lated duck nests. Canadian Journal of Zoology 79: 16041608.

Larivière, S., and F. Messier. 2001b. Temporal patterns of predation on duck nests in the Canadian prairies. American Midland Naturalist 146: 339-344.

Larivière, S., and L. R. Walton. 1998. Eggshell removal by duck hens following partial nest depredation by striped skunk. Prairie Naturalist 30: 183-185.

Martin, T. E. 1995. Avian life history evolution in relation to nest sites, nest predation, and food. Ecological Monographs 65: 101-127.

Pasitschniak-Arts, M., and F. Messier. 1995. Risk of predation on waterfowl nests in the Canadian prairies: effects of habitat edges and agricultural practices. Oikos 73: 347355.

Pasitschniak-Arts, M., and F. Messier. 1996. Predation on artificial duck nests in a fragmented prairie landscape. Écoscience 3: 436-441.

Reynolds, R. E., T. L. Shaffer, R. W. Renner, W. E. Newton, and B. D. J. Batt. 2001. Impact of the Conservation
Reserve Program on duck recruitment in the U.S. Prairie Pothole Region. Journal of Wildlife Management 65: 765780.

Ricklefs, R. E. 1969. An analysis of nesting mortality in birds. Smithsonian Contributions to Zoology 9: 1-48.

Shirer, H. W., and H. S. Fitch. 1970. Comparison from radiotracking of movements and denning habits of the raccoon, striped skunk, and opossum in northeastern Kansas. Journal of Mammalogy 51: 491-503.

Storm, G. L. 1972. Daytime retreats and movements of skunks on farmlands in Illinois. Journal of Wildlife Management 36: 31-45.

Verts, B. J. 1967. The biology of the striped skunk. Ph.D. thesis, University of Illinois, Urbana.

Vickery, P. D., M. L. Hunter, Jr., and J. V. Wells. 1992. Evidence of incidental nest predation and its effects on nests of threatened grassland birds. Oikos 63: 281-288.

Received 18 August 2005

Accepted 23 April 2007 